\title{
The humanitarian assistance dilemma explained: the implications of the refugee crisis in Tanzania in 1994
}

\section{Wen-Chin Lung}

To cite this article: Wen-Chin Lung (2019) The humanitarian assistance dilemma explained: the implications of the refugee crisis in Tanzania in 1994, Global Change, Peace \& Security, 31:3, 323-340, DOI: $10.1080 / 14781158.2019 .1635105$

To link to this article: https://doi.org/10.1080/14781158.2019.1635105

曲 Published online: 01 Jul 2019.

Submit your article to this journal $๘$

III Article views: 602

Q View related articles $₫$

View Crossmark data $־$ 


\title{
The humanitarian assistance dilemma explained: the implications of the refugee crisis in Tanzania in 1994
}

\author{
Wen-Chin Lung \\ Policy Research Division, National Applied Research Laboratories, Taipei, Taiwan
}

\begin{abstract}
Despite the good intention of humanitarian agencies, humanitarian assistance and relief aid exacerbated the humanitarian crisis in Tanzania during 1994. In the case of Tanzania, humanitarian assistance relieved belligerents' burden of sustaining conflicts, created safe spaces for armed combatants, undermined local economies, bestowed legitimacy upon belligerents, and fed armed combatants. This situation hence posed the typical humanitarian assistance dilemma for humanitarian agencies. While most scholars and aid practitioners suggest that humanitarian agencies should withdraw their assistance in these contexts given aid's apparent negative impact, there is relatively little research that properly identifies different kinds of ethical constraints and moral dilemmas that have long challenged humanitarian agencies. Referencing the case of late twentiethcentury Tanzania, this article contextualises the humanitarian assistance dilemma and systematically examines the ethical predicaments that surround it. Its analysis sheds light on moral quandaries that humanitarian agencies need to address in conflict situations.
\end{abstract}

\section{ARTICLE HISTORY}

Received 24 April 2018

Accepted 15 May 2019

\section{KEYWORDS}

Humanitarian assistance; conflict; refugees; aid agencies; humanitarian dilemma; relief aid

\section{Introduction}

Despite the good intention of humanitarian agencies, humanitarian assistance and relief aid exacerbated the humanitarian crisis in Tanzania during 1994. In the case of Tanzania, humanitarian assistance relieved belligerents' burden of sustaining conflicts; created safe spaces for armed combatants; undermined local economies; bestowed legitimacy upon belligerents; and fed armed combatants. ${ }^{1}$ This situation hence posed the typical humanitarian assistance dilemma for humanitarian agencies. Although the shifting nature of conflicts may pose new challenges to humanitarian agencies, the fundamental humanitarian assistance dilemma that confronts these agencies remains the same, regardless of which agency or conflict location. ${ }^{2}$

CONTACT Wen-Chin Lung wenchinlung@gmail.com

${ }^{1}$ Note that the term 'belligerents' is used as a broad term to include rebel groups, warring parties, militants, warlords, and insurgents.

2Joseph Carens, 'The Problem of Doing Good in a World That Isn't: Reflections on the Ethical Challenges Facing INGOs', in Ethics in Action, eds. D. Bell and J. Coicaud (Cambridge: Cambridge University Press, 2007), 257-72; Fiona Terry, 'Reconstituting Whose Social Order? NGOs in Disrupted States' (paper presented at the conference entitled From Civil Strife to Civil Society: Civil-Military Cooperation in Disrupted States, Canberra, Australia, July 6-7, 1999). 
While most scholars and aid practitioners suggest that humanitarian agencies should withdraw their assistance in these contexts, given the apparent negative impact of their aid, there is relatively little research that properly identifies different kinds of ethical constraints and moral dilemmas that have long challenged humanitarian agencies. Referencing the case of late twentieth-century Tanzania, this article contextualises the humanitarian assistance dilemma and systematically examines the ethical predicaments that surround it. By analysing the different manifestations of this dilemma in the refugee crisis in Tanzania in 1994, this article sheds light on particular kinds of moral quandaries confronting humanitarian agencies.

Tanzania has been chosen because it has presented a comparatively clear case of the humanitarian assistance dilemma, its corresponding ethical predicaments, and its impact on the humanitarian community. For example, it was found that the presence of armed combatants in the refugee-populated areas and the militarisation of refugee camps was the most notable in Tanzania, compared to the humanitarian crisis in other countries. ${ }^{3}$ It was also found that local markets had been severely affected as a result of the influx of aid, which drove down the prices of locally produced goods. The result was an over-dependence on aid by local authorities and victims, which further eroded an already fragile economy. ${ }^{4}$ Tanzania also provides an example of a man-made catastrophe which generated large numbers of refugees that the state was too weak to maintain control of due to fragility in the political and economic systems. During the Rwanda Crisis in the 1990s, approximately 700,000 Rwandan refugees entered Tanzania, which exacerbated political instability and intensified the already fragile economic situation in Tanzania. ${ }^{5}$ Tanzania hence illustrates how the humanitarian assistance dilemma can manifest, as well as different ways in which ethical predicaments can occur.

This situation is reflected in most present-day conflicts, including the conflict in Somalia in 2012, the war fought in Yemen in 2013, and the insurgencies that took place in occupied Palestinian territory in 2014, all of which share certain similarities with Tanzania's refugee crisis. ${ }^{6}$ In this sense, Tanzania's history, particularly the Rwanda Crisis in 1994, presents an exemplary case of the types of conditions and emergency scenarios that have important implications for other countries and are indicative of how the humanitarian assistance dilemma can arise. While the overall situation on the African continent has evolved since the field reports and research findings were conducted, the main thrust of the findings and the implications presented remain valid.

Before proceeding, it is important to note that the article is a work of moral theory and political philosophy, rather than a work of sociology, anthropology, or ethnography. Hence, there are no interviews involved, and there was no field research conducted.

\footnotetext{
${ }^{3}$ James Milner, Refugees, the State and the Politics of Asylum in Africa (Basingstoke: Palgrave Macmillan, 2009); Edward Mogire, 'Preventing or Abetting: Refugee Militarization in Tanzania', in No Refuge: The Crisis of Refugee Militarization in Africa, ed. Robert Muggah (London, UK: Zed Books, 2006), 137-68.

${ }^{4}$ Milner, Refugees, the State and the Politics of Asylum in Africa.

${ }^{5}$ ibid.

${ }^{6}$ Development Initiatives, the Global Humanitarian Assistance (GHA) Report 2013, the Global Humanitarian Assistance programme of Development Initiatives, 2013.; the Global Humanitarian Assistance (GHA) Report 2014, the Global Humanitarian Assistance programme of Development Initiatives, 2014.; the Global Humanitarian Assistance (GHA) Report 2015, the Global Humanitarian Assistance programme of Development Initiatives, 2015.
} 
Tanzania and some other countries are referred to with the use of secondary resources as illuminating cases to help facilitate exposition and underpin arguments. The article also uses a range of primary documents from Médecins Sans Frontières (MSF) and other humanitarian agencies.

\section{Tanzania from 1960 to 1994}

After gaining independence in the 1960s, Tanzania hosted tens of thousands of refugees fleeing national liberation movements and post-colonial conflicts. Back then, Tanzania was regarded as one of the most hospitable asylum-granting countries in Africa. ${ }^{7}$ However, such an open-door policy of asylum-granting changed in the 1990s. This was due in large part to the magnitude of refugee population inflows since the 1960s, the economic breakdown in Tanzania in the 1980s, the shifting of Tanzanian authorities' political ideology in the 1990s, the security concerns provoked by refugees in Tanzania after the Rwandan Crisis in 1994, and the overall lack of support from the international community to help deal with this crisis. ${ }^{8}$

From the 1960s to the 1970s, motivated by the former President Julius Kambarage Nyerere's economic strategy, an open asylum policy was implemented in Tanzania. Nyerere regarded the presence of refugees as advantageous because they helped attract support from international donors. Nyerere intended to accommodate as many refugees as possible to attract funds to accelerate Tanzania's economic development. ${ }^{9}$ The settlement of refugees in Tanzania was, therefore 'guided by the concepts of permanence and productivity, stemming ... from the principles on which the President ... hoped to develop his country'. ${ }^{10}$ In fact, Nyerere's strategy was to use refugees as a tool purely for economic matters. ${ }^{11}$

In addition to his economic development strategy, Nyerere provided support to liberation movements in other African countries during this period in following his 'pan-Africanism' political ideology. ${ }^{12}$ Tanzania adopted 'a strategy of encouraging and supporting armed struggles by the African populations'. ${ }^{13}$ As a result of this ideology, Tanzania harboured rebel movements which allowed armed combatants to recruit refugees as their soldiers, to receive contributions from refugees, and to use refugee camps to launch insurgencies. ${ }^{14}$ For instance, Tanzania was charged with exacerbating the civil war in Burundi by providing military training for rebel groups at its border, as well as supporting rebel groups' liberation movements in the 1970s. ${ }^{15}$

The intensity of conflict between Tanzania and its neighbouring countries since the 1960s, the collapse of its domestic economies in the 1980s, and the Rwanda crisis in the 1990s would eventual lead to Tanzanian authorities being labelled as a failed state.

\footnotetext{
${ }^{7}$ Milner, Refugees, the State and the Politics.

${ }^{8}$ Ibid.

${ }^{9}$ lbid.

${ }^{10}$ Zarjevski Yéfime, A Future Preserved: International Assistance to Refugees (Oxford: Pergamon Press, 1988), 137.

${ }^{11}$ Ibid.

${ }^{12}$ Milner, Refugees, the State and the Politics.

${ }^{13}$ Okwudiba Nnoli, Ethnic politics in Nigeria (Enugu: Fourth Dimension Publishers, 1978), 80.

${ }^{14}$ Mogire, 'Preventing or Abetting'.

${ }^{15}$ Note that the term 'rebel groups' is used as a broad term to include belligerents, warring parties, armed combatants, militants, warlords, and insurgents.
} 


\section{The refugee crisis in Tanzania in 1994}

From Rwandan Independence in 1962 to April 1994, around 50,000 Tutsi Rwandese refugees fled to Tanzania. ${ }^{16}$ Most of them were initially settled in a camp at Muyenzi in the Ngara district and later at a camp at Mwesi. ${ }^{17}$ According to Human Rights Watch (HRW), in the space of 100 days between April and July 1994, at least half a million Tutsis were killed, amounting to 'three quarters of the Tutsi population of Rwanda'. ${ }^{18}$ Overall, an estimated 800,000 Rwandans died in Rwanda. ${ }^{19}$ Following the murders of the former Rwandan President Juvénal Habyarimana and former Burundian President Cyprien Ntyamina on 6 April 1994, there was an increased influx of refugees to Tanzania.

The Tanzanian government hosted approximately '255,000 refugees in Benaco camp, 98,000 in Lumasi and 30,000 in Musuhura' in response to the unprecedented flow of refugees. ${ }^{20}$ Despite its reputation as one of the most welcoming asylum countries, Tanzania was accused of encouraging and supporting rebel groups in their armed movements. As noted earlier, Tanzanian authorities were found to harbour rebel movements against Burundi. In a similar vein, during the Rwanda Crisis in the 1990s, it was found that Forces Armées Rwandaises (FAR) were present in the Tanzanian camps, where military structures existed and stocks of arms and training activities were found. ${ }^{21}$

Shocked by the unprecedented scale of people in need affected by the Rwanda Crisis, many humanitarian agencies established their presence as a response. International humanitarian agencies such as the International Committee of the Red Cross (ICRC), Médecins Sans Frontières (MSF), and Oxfam (UK and Ireland) launched numerous humanitarian projects throughout the Great Lakes region of Africa during the crisis. While Oxfam (UK and Ireland) launched one of the largest emergency operations in response to this disaster, MSF provided ample relief aid and medical resources to the affected population. ${ }^{22}$ According to Guy Vassall-Adams, most of the operations were performed by 'ICRC (food supplies), MSF (health care), Oxfam (water supplies) and CARE (non-food items)' ${ }^{23}$

However, during this crisis humanitarian assistance and relief aid provided by humanitarian agencies exacerbated the conflict and intensified the on-going suffering, despite their good intentions. This situation posed the typical humanitarian assistance dilemma for aid agencies: seeing that their humanitarian efforts can cause more harm overall, humanitarian agencies often have to decide whether to withdraw their assistance. In the case of Tanzania, the humanitarian assistance dilemma manifests itself in five main

\footnotetext{
${ }^{16}$ Guy Vassall-Adams and Oxfam, Rwanda: An Agenda for International Action (Oxford: Oxfam Publications, 1994).

${ }^{17}$ lbid.

${ }^{18}$ Alison Des Forges, Leave None to Tell the Story: Genocide in Rwanda, Human Rights Watch, March 1999.

${ }^{19}$ Ibid.

${ }^{20}$ Médecins Sans Frontières-Holland, Breaking the Cycle: MSF Calls for Action in the Rwandese Refugee Camps in Tanzania and Zaire: Médecins Sans Frontières-Holland Report, 1994, 4.

${ }^{21}$ Médecins Sans Frontières-Belgium, Médecins Sans Frontières-France, Médecins Sans Frontières-Holland, Médecins Sans Frontières-Luxembourg, and Médecins Sans Frontières-Spain. Minutes of: The International Meeting of Operations Directors (in English) (Paris: Médecins Sans Frontières, 1994); Médecins Sans Frontières-Holland, Breaking the Cycle; Médecins Sans Frontières-Holland, Arjo Berkhout, MSF Holland Coordinator in Tanzania from April to July 1994: Our Aid Is Keeping Criminal Power Structures Intact, Ins and Outs, MSF Holland internal publication, September 1994; Médecins Sans Frontières-USA, MSF Withdraws Teams from Rwandan Refugee Camps in Tanzania, MSF-USA Press release, December 1994.

${ }^{22}$ Laurence Binet, 'Rwandan Refugee Camps in Zaire and Tanzania, 1994-1995 Médecins Sans Frontières Internal Document', Genève: Médecins Sans Frontières International (2005a); 'Genocide of Rwandan Tutsi, 1994 Médecins Sans Frontières Internal document', Genève: Médecins Sans Frontières International (2005b); Vassall-Adams and Oxfam, Rwanda: An Agenda for International Action.

${ }^{23}$ Vassall-Adams and Oxfam, Rwanda: An Agenda for International Action, 49.
} 
ways in the context of conflict: humanitarian assistance relieved armed combatants' burden of sustaining conflicts; created safe spaces for armed combatants; undermined local coping strategies; bestowed legitimacy upon armed combatants; and fed armed combatants. This will be discussed further below.

Overall, the example of Tanzania shows three important facts. First, it shows that humanitarian agencies, in effect, profess differing fundamental purposes, humanitarian operational principles, and organisational mandates when carrying out humanitarian operations. Second, it reflects that, due to such differences, humanitarian agencies lack a clear consensus regarding which action is the right one to take and also which right action to prioritise in the face of the humanitarian assistance dilemma. Finally, it clearly depicts the kind of humanitarian assistance dilemma and ethical predicaments facing humanitarian agencies (which will be shown in the subsequent discussion).

Before proceeding, it is important to note that this article focuses on humanitarian agencies that concentrate on relief aid and humanitarian assistance provision in fragile and conflict-affected settings, such as ICRC and MSF. Therefore, bilateral and multilateral aid that state actors, governments, or governmental organisations provide will not be taken into account. The humanitarian agencies stated above may profess different mandates: some may profess a charitable duty to assist the most vulnerable, whereas others may base their action on the basic human rights of individuals by virtue of humanity. Nevertheless, they all have certain important humanitarian features in common - the humanitarian agencies noted above all have the common objective of alleviating the affected population's suffering and prioritising the concern for humanity over other considerations. $^{24}$

Most importantly, these humanitarian agencies all face the humanitarian assistance dilemma that agencies working exclusively on development projects would not face. This is because humanitarian agencies such as MSF often perform humanitarian operations in the context of violence or insecurity, in contrast to development agencies. ${ }^{25}$ Humanitarian agencies' frequent struggles with the humanitarian assistance dilemma are also due in large part to their commitment to humanitarian guiding principles, such as neutrality and impartiality, which is not the case for agencies working in development projects. $^{26}$

\section{Five humanitarian assistance dilemma manifestations}

The humanitarian assistance dilemma can arise in five crucial ways, and each way respectively poses an ethical predicament for humanitarian agencies.

\section{Reducing armed combatants' costs}

Humanitarian assistance can relieve armed combatants' burden of sustaining costly conflicts by providing material resources armed combatants need to finance their

\footnotetext{
${ }^{24}$ Carens, 'The Problem of Doing Good'; Fiona Terry, 'Reconstituting Whose Social Order?'

${ }^{25}$ Michael Barnett, The Empire of Humanity: A History of Humanitarianism (Ithaca, NY: Cornell University Press, 2011).

${ }^{26}$ Caroline Abu-Sada, In the Eyes of Others: How People in Crises Perceive Humanitarian Aid (Médecins Sans Frontières-USA, 2012); Larissa Fast, Aid in Danger: The Perils and Promise of Humanitarianism (Philadelphia: University of Pennsylvania Press, 2014); Dorothea Hilhorst, The Real World of NGOs: Discourses, Diversity and Development (London: Zed Books, 2003).
} 
attacks and support their insurgencies. Humanitarian assistance, therefore, can be used as an instrument for armed combatants to exploit and benefit from. ${ }^{27}$ Armed combatants often misappropriate material and food resources that are meant to help the affected population, regardless of humanitarian agencies' unwillingness. As a result, relief aid is found to enable armed combatants to launch less costly attacks.

For instance, Samantha Bolton's research on Rwandan refugee camps in Tanzania demonstrates that those 'whom were suspected of participating in the genocide... were officially assigned to draw up lists of beneficiaries and to organise distributions of food aid provided by the World Food Programme (WFP), much of which they misappropriated'. ${ }^{28}$ Sarah Lischer's findings also suggest that armed combatants benefitted from exaggerating the number of refugees present, in addition to misappropriating huge quantities of relief aid and humanitarian resources to sustain costly conflicts. ${ }^{29}$ Furthermore, according to Lischer and James Milner, armed combatants often hid their families in the camps in order to relieve their demands of food and goods. ${ }^{30}$ For example, it was found that armed combatants settled their family members in the refugee camp 'as a destination for rest and relaxation, and as a source for supplies'.31 Finally, John Prendergast points out that 'selling or trading diverted commodities' was 'a principal method of obtaining weapons for armed combatants in conflicts'. ${ }^{32}$ Humanitarian assistance, to that extent, relieved armed combatants' burdens to sustain costly conflicts.

While humanitarian assistance can therefore provide incentives for conflicts by relieving armed combatants' burdens to feed their family members, it also incentivises conflict by intensifying existing suffering. According to a report conducted in 1994 by MSF, it was evident at that time that the 'distribution of humanitarian relief is being controlled and aid is often diverted by community leaders, many of whom themselves are suspected of having been involved in the genocide', which resulted in the prolongation of the Rwandan conflict. ${ }^{33}$ This further supports the claim that humanitarian assistance has, in effect, relieved the burden of armed combatants. Knowing that their humanitarian assistance could be and had been misused or used against those whom it was supposed to support, agencies such as MSF-France decided to withdraw their support in the face of the obvious negative impact of their assistance. ${ }^{34}$

The corresponding ethical predicament, therefore, is this: should humanitarian agencies stay and continue to assist the current affected population but risk providing incentives for conflicts?

\footnotetext{
${ }^{27}$ Milner, Refugees, the State and the Politics; David Rieff, A Bed for the Night: Humanitarianism in Crisis (London: Vintage, 2002).

${ }^{28}$ Samantha Bolton, Press and Tanzania/ Rwanda Crisis, International Press Officer for East Africa, May 1994, 2.

${ }^{29}$ Sarah Lischer, 'Dangerous Sanctuaries: Refugee Camps, Civil War, and the Dilemmas of Humanitarian Aid', Cornell Studies in Security Affairs (2005): 204.

${ }^{30}$ Milner, Refugees, the State and the Politics.

${ }^{31}$ Ibid., 152.

${ }^{32}$ John Prendergast, Frontline Diplomacy: Humanitarian Aid and Conflict in Africa (Boulder and London: Lynne Rienner 1996), 22.

${ }^{33}$ Médecins Sans Frontières-Holland, Breaking the Cycle, 1. Note that this specific humanitarian assistance dilemma, namely reducing armed combatants' costs, also happened in Zaire (the former DR Congo).

${ }^{34}$ Fiona Terry and Bianca Cordaro, Message from MSF France Coordinator in Ngara (Tanzania) to MSF France Programme Manager, 4 October 1994 (in English).
} 


\section{Providing safe spaces for armed combatants}

The humanitarian assistance dilemma can also arise when humanitarian agencies create safe spaces for armed combatants, leading to the forced recruitment of refugees, the militarisation of refugee camps, and human rights violations in refugee-populated areas. Relief aid and humanitarian resources delivered to refugee camps often provide cover for armed combatants and further facilitate the process of the militarisation of refugee camps. In addition, humanitarian assistance and the aid provided also enable armed combatants to conduct human rights violations. ${ }^{35}$

For example, doctor Bernard Pécoul, the MSF-France Executive Director at the time, argued that 'the rehabilitation of the torturers under cover of international humanitarian aid' was found everywhere in the Rwandan refugee camp in Benaco (Tanzania), which made the camp 'a humanitarian façade' ${ }^{36}$ The control of the Benaco camp by the armed combatants responsible for genocide made it, as termed by Doctor Bernard Pécoul, a 'Hutu stronghold'. ${ }^{37}$ Moreover, the presence of armed combatants in the camps in Tanzania severely threatened the lives of refugees in these camps. Human rights violations were also identified in refugee settlements. For instance, Nicolas de Torrente, MSF-France's administrator in Tanzania between 1993 and 1994, found that humanitarian assistance to refugee camps not only provided a perfect cover for armed combatants to hide, it also enabled them to conduct killings more easily. ${ }^{38}$

Other human rights violations such as forced recruitment were also evident at that time. According to MSF-USA, 'military training of refugees is openly conducted near the camps', and 'killings and intimidation in the camps happen on a daily basis', where 'refugees in the camps are not free to choose whether to return or not'. ${ }^{39}$ In a similar vein, Mogire found that armed combatants in Tanzania not only recruited and trained refugees; they also used refugee camps to conduct cross-border insurgencies. ${ }^{40}$ According to Integrated Regional Information Networks (IRIN), there was strong evidence indicating that forced recruitment and forced-taxation were taking place inside refugee camps in Tanzania. ${ }^{41}$ Given that some humanitarian agencies, such as MSF-France, were uncertain about the identities of armed combatants that hid and rested in the camp, they were incapable of distinguishing between armed combatants and genuine refugees. ${ }^{42}$

Another example was found in some of MSF's minutes recorded in 1994. According to the minutes, Hutu rebel groups' armed movements were 'well organised with lists' and local leaders hiding in the camps had 'total control of the population', which made the camp 'become a haven for the FAR, shielded by the civilian population'. ${ }^{43}$ Furthermore, it was evident that 'the figures stating number of refugees in the camp has been

\footnotetext{
${ }^{35}$ Binet, 'Rwandan Refugee Camps'; 'Genocide of Rwandan Tutsi'; Bolton, 'Press and Tanzania/ Rwanda Crisis'; Corine Lesnes, 'Rwandan Killers and Refugees: Among the Hundreds of Thousands of Hutu Who Fled to Tanzania Are Those Who Murdered Tutsi', Le Monde (France), June 11, 1994, http://speakingout.msf.org/en/node/437; Médecins Sans FrontièresHolland, 'Breaking the Cycle'; Médecins Sans Frontières-Holland, Our Aid Is Keeping Criminal Power.

${ }^{36}$ Binet, 'Genocide of Rwandan Tutsi', 51.

${ }^{37}$ Ibid.

${ }^{38}$ Cited in Binet, 'Rwandan Refugee Camps'; 'Genocide of Rwandan Tutsi'.

${ }^{39}$ Médecins Sans Frontières-USA, MSF Withdraws Teams, 1.

${ }^{40}$ Mogire, 'Preventing or Abetting'.

${ }^{41}$ Ibid.

${ }^{42}$ Bolton, 'Press and Tanzania/ Rwanda Crisis'.

${ }^{43}$ Médecins Sans Frontières-Belgium., Médecins Sans Frontières-France., Médecins Sans Frontières-Holland, Médecins Sans Frontières-Luxembourg, and Médecins Sans Frontières-Spain, Minutes of the International Meeting.
} 
overestimated' by armed combatants in order to attract more influx of aid for their own use. ${ }^{44}$ According to the data retrieved from the report MSF calls for action in the Rwandese refugee camps in Tanzania and Zaire, there is evidence that FAR were present in the Tanzanian camps, where military structures existed, and stocks of arms and training activities were found. Specifically, in 'the former Rwandese army' section of MSF's report, it states that

the FAR is present in the camps in Zaire, Mugunga near Goma and Chimanga near Bukavu and in the Tanzanian camps. They live with their families among the refugees. A military structure continues to exist and stocks of arms and training activities have been reported. The market in Mugunga camp is extremely well-supplied and bags of relief goods are openly being traded. ${ }^{45}$

Terry also supports this finding by stating that armed combatants used protected camps and aid to enclave safe zones to rest and recruit combatants. ${ }^{46}$

Thus, the humanitarian assistance dilemma creates protected safe spaces for armed combatants. Furthermore, Narang finds that this phenomenon is on-going, with humanitarian assistance still being misused by armed combatants to hide, recruit more armed combatants, and to launch further attacks. ${ }^{47}$ These findings further support the argument that although humanitarian assistance provides help to refugees in camps, it can also become a cover, providing protected safe spaces for armed combatants. When humanitarian assistance creates protected safe spaces for armed combatants, human rights violations can arise. To conclude, humanitarian agencies often have no choice but to provide humanitarian assistance not only to the genuine refugees but also to the armed combatants in camps as well. By creating safe spaces and covers for combatants, humanitarian aid agencies are often forced to facilitate, and therefore condone, obvious human rights violations in these refugee camps and settlements.

The corresponding ethical predicament facing humanitarian agencies then is this: should humanitarian agencies stay and continue to assist the current affected population but risk encouraging human rights violations?

\section{Undermining local economies}

The humanitarian assistance dilemma may also arise when humanitarian assistance undermines local coping strategies to deal with crises. In times of conflict, humanitarian assistance can strengthen the existing power relations of the camp and further support wartime economies. This phenomenon often erodes local capacities to deal with emergencies and further collapses local economies. In addition to undermining local coping strategies and paralysing local economies, humanitarian assistance can also stunt development, corrupt social structures, weaken peacetime productivity, and exacerbate market imbalances. ${ }^{48}$ In

\footnotetext{
${ }^{44}$ lbid.

${ }^{45}$ Médecins Sans Frontières-Holland, Breaking the Cycle: MSF Calls for Action in the Rwandese Refugee Camps in Tanzania and Zaire: Médecins Sans Frontières-Holland Report, 1994, 7.

${ }^{46}$ Fiona Terry, Condemned to Repeat? The Paradox of Humanitarian Action (Ithaca, London: Cornell University Press, 2002).

${ }^{47}$ Neil Narang, 'Assisting Uncertainty: How Humanitarian Aid Can Inadvertently Prolong Civil War', International Studies Quarterly 59, no. 1 (2015): 184-95.

${ }^{48}$ Mary Anderson, 'You Save My Life Today, but for What Tomorrow?', in Hard Choice: Moral Dilemmas in Humanitarian Intervention, ed. Jonathan Moore (Lanham, MD: Rowman \& Littlefield, 1998); Mary Anderson, Do No Harm: How Aid Can Support Peace-Or War (London: Lynne Rienner Publishers, 1999); Nicholas Stockton, 'Humanitarian Values: Under Siege from Geopolitics', Unpublished paper (2003).
} 
these situations, the affected population is often forced to continue to rely on relief aid for survival. This has contributed to their dependence on aid significantly. As Mary Anderson notes in her findings, the influx of humanitarian resources often reinforces individuals' interests in maintaining wartime economies, especially in situations where conflicts have disrupted local economies so severely that almost no local capacities exist. ${ }^{49}$

Humanitarian assistance can also encourage wartime economies. In an interview with Françoise Bouchet-Saulnier (MSF's senior legal adviser at that time) conducted by JeanClaude Raspiengeas, Bouchet-Saulnier blames humanitarian agencies for supporting wartime economies. She argues that it was through humanitarian agencies and humanitarian assistance that 'the Hutu government lost the war but maintains control of the population and economic resources'. ${ }^{50}$ Bouchet-Saulnier therefore argues that withdrawing aid was necessary because it was evident that the Hutu government's 'entire economic survival is ... based on this bluff and trafficking of aid'. ${ }^{51}$

In addition to supporting wartime economies, Bouchet-Saulnier argues that humanitarian assistance also reinforced the existing power structures in camps, which resulted in refugees' further dependence on relief aid. ${ }^{52}$ This phenomenon is particularly evident when armed combatants misappropriate humanitarian resources and resell relief aid to refugees. For example, in the Ngara refugee camp in Tanzania it was found that 'many water points are ... under the control of a man known to UNHCR who sells the water to the refugees'. ${ }^{53}$ It was also found that armed combatants were able to set up a taxation system on food, which combatant leaders profited from because of the power they had gained in the camp. ${ }^{54}$ This situation can make refugees in camps even more vulnerable and more in need of aid.

Through supporting wartime economies and strengthening the existing power imbalance in camps, humanitarian assistance can further contribute to the already vulnerable refugees' dependency on aid. Alain Destexhe's field report has supported this claim. In his report, it was evident that the armed combatants of the former Rwandan government were able to 'consolidate their power over the 300,000 Rwandans' only because they used 'the daily food distributions' as a bargain. ${ }^{55}$ Furthermore, Destexhe's report suggests that refugees were made even more dependent on relief aid in situations where local economies were disrupted, and humanitarian resources were under the control of armed combatants. ${ }^{56}$ According to the report, armed combatants had received more aid by making up the numbers of refugees, and this had successfully persuaded refugees to remain in camps. By controlling the aid, armed combatants had also successfully kept refugees under their control: refugees were found to remain in the camp not only because local economies were too weak to sustain their basic livelihood, but also because armed combatants had control over aid resources. This demonstrates that humanitarian assistance can make refugees even more vulnerable and more dependent on aid in the long run. After all, in situations where humanitarian assistance undermines local capacities,

\footnotetext{
${ }^{49}$ Anderson, Do No Harm.

${ }^{50}$ Binet, 'Rwandan Refugee Camps', 28.

${ }^{51}$ Ibid., 28.

${ }^{52}$ lbid.

${ }^{53}$ Terry and Cordaro, Message from MSF France coordinator in Ngara (Tanzania), 1.

${ }^{54}$ Ibid.

${ }^{55}$ Binet, 'Genocide of Rwandan Tutsi', 34.

${ }^{56}$ Ibid.
} 
reinforces wartime economies, and strengthens the existing power imbalance, refugees are more inclined to depend on aid and are often made more vulnerable.

The corresponding ethical predicament is this: should humanitarian agencies stay and continue to assist the current affected population but risk undermining local economies?

\section{Bestowing legitimacy upon armed combatants}

The humanitarian assistance dilemma can also arise when humanitarian assistance legitimises armed combatants' unjust regimes. Humanitarian agencies are often forced to negotiate with armed combatants who are in control of refugee camps to get access to the affected population. This includes agreeing to hire armed combatants as a safeguard and paying taxes to armed combatants. To that extent, humanitarian agencies have contributed to armed combatants' perceived legitimacy. Through their collaboration and cooperation with the armed combatants, humanitarian agencies bestow legitimacy. According to Anderson, armed combatants often perceive their regimes as legitimate and lawful, due in large part to humanitarian agencies' cooperation and collaboration with them. ${ }^{57}$ They hence come to expect that 'external aid agencies will comply with the rules and restrictions they impose in their area of command'. ${ }^{58}$

The findings of several reports, including those by MSF-USA and MSF-France, also support the claim that armed combatants often establish their legitimacy to rule over refugee populations through collaborating and cooperating with humanitarian agencies in the field. ${ }^{59}$ For instance, by hiring 'a group of 300 Rwandans to oversee security during registration and food distributions and to patrol in the camps', who appeared to be complicitous with the armed combatants, United Nations High Commissioner for Refugees (UNHCR) had strengthened armed combatants' authority to control the camps and legitimised armed combatants' rule over refugee populations. ${ }^{60}$

Another example can be found in MSF-USA's press release in 1994. The press release suggested that their collaboration with armed combatants strengthened and legitimised 'the power of leaders of a regime which organized and perpetrated a genocide', which left them no choice but to withdraw their assistance from Rwandan refugee camps in Tanzania. ${ }^{61}$ According to the press release, armed combatants were appointed as 'the official and paid mediators between the aid agencies and the refugees', who were in charge of selecting 'the candidates for the refugee police force or guardians' in refugee camps in Tanzania. ${ }^{62}$ To that extent, humanitarian agencies helped to institutionalise armed combatants' power and legitimacy in camps, and bestowed legitimacy upon them by granting them the right to select candidates in camps and rule over refugees. Knowing that they had legitimised armed combatants' unjust regime, MSF-USA decided to withdraw their assistance in order to avoid being complicit in armed combatants' wrongdoing. ${ }^{63}$

\footnotetext{
${ }^{57}$ Anderson, Do No Harm.

${ }^{58}$ Ibid., 50 .

${ }^{59}$ Binet, 'Rwandan Refugee Camps' and 'Genocide of Rwandan Tutsi'; Médecins Sans Frontières-USA, MSF Withdraws Teams; Terry and Cordaro, Message from MSF France Coordinator in Ngara (Tanzania).

${ }^{60}$ Binet, 'Rwandan Refugee Camps', 13.

${ }^{61}$ Médecins Sans Frontières-USA, MSF Withdraws Teams, 1.

${ }^{62}$ lbid., 1.

${ }^{63}$ Médecins Sans Frontières-USA, MSF Withdraws Teams.
} 
Furthermore, MSF-France's report suggested that 'it is very clear that humanitarian aid to the Rwandan refugees helps maintain the power of the leaders' because 'all NGOs and UN agencies working in the Tanzania camps operate through a structure which reinforces the control of the leaders'. ${ }^{64}$ This situation was found to further empower 'the leaders ... to ensure compliance [with] this system of taxation' ${ }^{65}$ Field reports of MSF-France and MSFUSA hence support the claim that humanitarian agencies can legitimise the armed combatants' unjust regime by collaborating and cooperating with them.

The corresponding ethical predicament that arises is this: should humanitarian agencies stay and continue to assist the current affected population but risk bestowing legitimacy upon armed combatants?

\section{Feeding armed combatants}

Finally, humanitarian assistance can directly feed armed combatants' basic needs through humanitarian agencies' commitment to the traditional humanitarian operational principles of impartiality and neutrality. This manifestation of the humanitarian assistance dilemma differs from the first manifestation of the dilemma (that is, the humanitarian assistance dilemma arising in situations where humanitarian assistance relieves armed combatants' cost). The latter involves the misappropriation of resources, while the former involves feeding all needy people impartially or neutrally.

The principles of impartiality and neutrality are two of the core principles of humanitarian action. The former focuses on providing aid according to need and without discrimination; the latter focuses on the importance of not taking sides in conflicts. ${ }^{66}$ The traditional operational principle of impartiality is regarded by many as one of the fundamental principles of humanitarian action, given that it guarantees an approach that is about assisting needy people in acute danger without discrimination. ${ }^{67}$ Impartiality, according to von Pilar, is a 'true reflection of ... humanity'. ${ }^{68}$ Bearing this in mind, humanitarian agencies often deliver humanitarian action and emergency assistance based on the operational principle of impartiality. However, this sometimes involves assisting armed combatants. This is because the operational principles of impartiality demand humanitarian agencies assist every needy person 'irrespective of their being part of any social, political, ethnic or another group'. ${ }^{69}$ Although a commitment to impartiality can help humanitarian agencies reflect their belief in humanity, it is viewed as outdated by many, given that it often benefits

\footnotetext{
${ }^{64}$ Terry and Cordaro, Message from MSF France Coordinator in Ngara (Tanzania), 1.

${ }^{65}$ Ibid., 1.

${ }^{66} \mathrm{Abu}-\mathrm{Sada}$, In the Eyes of Others; European Civil Protection and Humanitarian Aid Operations (ECHO) and Overseas Development Institute (ODI). Report of: ECHO/ ODI Conference on Principled Aid in an Unprincipled World: Relief, War and Humanitarian Principles. London, ECHO and ODI, 1998; Fast, Aid in Danger; Marion Harroff-Tavel, 'Neutrality and Impartialitythe Importance of These Principles for the International Red Cross and Red Crescent Movement and the Difficulties Involved in Applying Them', International Review of the Red Cross 29, no. 273 (1989): 536-52; Peter Hoffman and Thomas Weiss, Sword \& Salve: Confronting New Wars and Humanitarian Crises (Lanham, MD: Rowman \& Littlefield, 2006); Larry Minear and Thomas Weiss, Humanitarian Action in Times of War: A Handbook for Practitioners (London: Lynne Rienner, 1993).

${ }^{67}$ Ulrike Von Pilar, 'Humanitarian Space under Siege Some Remarks from an Aid Agency's Perspective', Background paper prepared for "the Symposium Europe and Humanitarian Aid - What Future? Learning from Crisis" (Neuenahr, Germany, 1999).

${ }^{68}$ Ibid., 3 .

${ }^{69}$ Ibid., 3.
} 
not only the genuine refugees but also the obvious wrongdoers (i.e. armed combatants, rebel groups, belligerents, etc.).

According to Nicolas de Torrente, MSF-France's administrator in Tanzania, although humanitarian agencies working in Tanzania could tell that the refugees were organised and there was a structure existing in the camp, they nevertheless continued to provide medical support to them, based on their operational principle of impartiality. ${ }^{70}$ As a result, 'huge quantities of food were distributed which the leaders resold. The same trucks that brought food in went back out again full'. ${ }^{71} \mathrm{MSF}^{\prime} \mathrm{s}$ medical mandate in aiding needy people impartially thus led to an unwanted outcome: tens of thousands of murderers received aid and were thereby enabled to conduct more killings as a result of this aid.

Another example of humanitarian assistance feeding armed combatants because of humanitarian agencies' commitments to impartiality can be found in a report by the Tanzanian Red Cross. The report clearly stated that doctors working in camps had helped to feed armed combatants and further enabled them to do more harm because of their belief in the principle of impartiality. Hervé Isambert, who worked for the Tanzanian Red Cross, for instance, saw the wounded murderers of Tutsi 'burst into the Rwandan hospital where he was working' and leave the camp upon recovery. ${ }^{72}$ Even though he knew that the patients he treated were killers and murderers, Isambert insisted that the principle of impartiality is of utmost importance since it is 'everything that humanitarianism stands for'. ${ }^{73}$ Also, Christine Pliche, a nurse working in the hospital in Rwanda, re-asserted her commitment to the traditional principle of impartiality: 'I work in medicine and I have my professional code of ethics' and because of this, 'I close my eyes and I treat people'. ${ }^{74}$

Furthermore, the spokesman of UNHCR at that time, Philippe Lamair, reiterates humanitarian agencies' mandate of impartiality and neutrality in delivering humanitarian assistance by arguing that 'qualms are a personal issue' which cannot be used to deny people's right to care. ${ }^{75} \mathrm{~A}$ manager from CARE even goes so far as to defend its commitment to traditional humanitarian operational principles of impartiality and neutrality by contending that, as humanitarian agencies, they cannot refuse to aid armed combatants just because they are the repressors. ${ }^{76}$

Finally, in Hanna Nolan's memo from the Department of Humanitarian Affairs of MSFHolland, MSF-Holland's head office defended and justified its position of staying in camps. $^{77}$ According to Nolan's memo, MSF-Holland's head office was struggling to decide whether to 'continue to give humanitarian aid to people', especially to 'whom it is said that while receiving the good care of the aid agencies they are preparing themselves for a return to Rwanda to continue their murderous practices'. ${ }^{78}$ MSF-Belgium staff who worked in the Benaco camp in Tanzania were found to have felt uneasy

\footnotetext{
${ }^{70}$ Cited in Binet, 'Rwandan Refugee Camps' and 'Genocide of Rwandan Tutsi'.

${ }^{71}$ Binet, 'Rwandan Refugee Camps', 13.

${ }^{72}$ Lesnes, 'Rwandan Killers and Refugees'.

${ }^{73}$ Ibid., 14.

${ }^{74}$ Ibid., 14.

${ }^{75}$ Ibid., 14.

${ }^{76}$ lbid.

${ }^{77}$ Médecins Sans Frontières-Holland, Breaking the Cycle; Our Aid Is Keeping Criminal.

${ }^{78}$ Hanna Nolan, Memo from the Department of Humanitarian Affairs, MSF Holland to all MSF Holland Staff Working or Having Worked in Benaco Camp' Presence of Alleged Perpetrators of Genocide in the Camp: Explanation of MSF Holland Position, MSF SPEAKING OUT, July 1994, 1.
} 
about aiding: 'individuals in the Benaco camp ... suspected of having participated in acts of genocide or other violations of human rights in Rwanda'. ${ }^{79}$ However, MSF-Holland's head office restated its commitment to the principle of impartiality: 'MSF's charter demands us to give humanitarian aid indiscriminately. We should continue our activities in the camp' because humanitarian agencies 'are not judges who would have the evidence to decide who is guilty of such a crime. After all, 'choosing to whom to give or not give aid would be impossible'. ${ }^{80}$

As Wouter Kok, MSF-Holland's coordinator in Tanzania at the time, puts it, we 'can have judgements but we cannot use our aid to punish the bad guys', given that it is 'not the role of a medical organisation'; 'it is up to a judge to decide who is to be punished'. ${ }^{81}$ Kok furthers this statement by arguing that 'we can advocate, and we can highlight a problem, but we should not use our relief - be it health care, be it food or be it water to distinguish between good and bad'. ${ }^{82}$ Having a strong commitment to the mandate of impartiality, humanitarian agencies often feel obliged to fulfil this commitment, even if it means that their aid will enable the 'bad guys' to launch further attacks and cause more suffering.

While the principle of impartiality can enable wrongdoers to take advantage of aid resources, the principle of neutrality can, furthermore, encourage repressors to continue to cause harm. The main difference between these two principles of humanitarian action lies in that the former can benefit wrongdoers by aiding indiscriminately, whereas the latter can encourage repressors to continue causing harm by making no judgements and staying silent. Through staying neutral, making no judgements and remaining silent on repressors' mass abuse of refugees, the principle of neutrality can encourage repressors to continue to cause harm. By committing to traditional operational principles of impartiality and neutrality, humanitarian agencies are often accused of 'being blind to injustice' and 'acting indiscriminately as quartermaster to the forces of ... evil'. ${ }^{83}$ This is mainly because humanitarian assistance often feeds armed combatants and enables them to cause more harm. Hence, humanitarian agencies and the assistance they provide often make the overall situation even more problematic, rather than alleviating genuine refugees' suffering.

This specific type of ethical predicament differs from the other four ethical predicaments discussed above. Instead of choosing between continuing their humanitarian operations and minimising negative impacts of aid, humanitarian agencies are forced to choose between upholding principles of impartiality and neutrality, and adopting different but equally important humanitarian operational principles to avoid harm.

\section{Overall ethical predicaments evaluated}

As shown above, humanitarian assistance and the relief aid provided can generate difficult ethical predicaments and have profound negative impacts on the affected population in conflict-affected settings. Knowing that aid can be counter-productive in humanitarian

\footnotetext{
${ }^{79}$ Binet, 'Rwandan Refugee Camps', 24.

${ }^{80}$ Nolan, Memo from the Department of Humanitarian Affairs.

${ }^{81}$ Binet, 'Rwandan Refugee Camps', 67.

${ }^{82}$ Ibid., 67.

${ }^{83}$ Stockton, 'Humanitarian Values', 6.
} 
crises, numerous theorists and aid practitioners have argued that humanitarian assistance should either be withdrawn or reallocated. This is based on the belief that, overall, humanitarian assistance has generated a more negative rather than positive impact on the affected population, and that aid should be delivered in a more cost-effective way that can reduce harm and preserve more lives. ${ }^{84}$

Granted that humanitarian assistance may have a profound negative impact, humanitarian agencies' efforts are still typically humanitarian - they operate missions (if not always solely) for reasons of humanity. It follows that simply focusing on the results of projects, such as the overall efficacy of humanitarian operations and the number of lives helped, is inadequate. Calculating all possible negative impacts of humanitarian assistance, after all, does not help humanitarian agencies navigate their decisions when confronted with a humanitarian assistance dilemma and its corresponding ethical predicaments. Starting with what can be measured, such as quantifiable indicators, rather than what should be measured can lead to 'meaningless evaluations' of humanitarian operations. ${ }^{85}$

Most of the existing literature on humanitarian assistance mainly considers the negative impact of humanitarian assistance and thus views the continuation of assistance as causing more harm. This trend in current humanitarian discourse therefore, unsurprisingly, is dominated by arguments on aid effectiveness and aid efficiency, in light of the view that humanitarian agencies should promote the best outcome. This requires humanitarian agencies to maximise the utility of relief aid and to withdraw their assistance to refugees if necessary. ${ }^{86}$ This phenomenon seems to have developed due to the popularity of a simple account of consequentialism for resolving the humanitarian assistance dilemma.

Humanitarian agencies often emphatically adopt a simple account of consequentialism to calculate costs and benefits when facing the humanitarian assistance dilemma. ${ }^{87}$ The scarcity of resources and the limitation of time further reinforce humanitarian agencies' belief that maximising the utility of aid and resources in a cost-effective way appears to be the most reasonable way to approach the humanitarian assistance dilemma. Given the fact that conflicts create mass-casualty triage, where the scarcity of resources and the limitation of time make it impossible to save all lives, humanitarian agencies often follow a utilitarian calculation, favouring the welfare of the larger number of people over that of the smaller number of people. ${ }^{88}$

\footnotetext{
${ }^{84}$ Ben Barber, 'Feeding Refugees, or War? The Dilemma of Humanitarian Aid', Foreign Affairs (1997): 8-14; Jonathan Glennie, 'More Aid Is Not the Answer', The Journal of Contemporary World Affairs (2010): 205; Lischer, 'Dangerous Sanctuaries'; Nathan Nunn and Nancy Qian, 'Aiding Conflict: The Impact of U.S. Food Aid on Civil War', the National Bureau of Economic Research (2012); Thomas Pogge, 'Moral Priorities for International Human Rights NGOs', in Ethics in Action, eds. D. Bell and J. Coicaud (Cambridge: Cambridge University Press, 2007a), 218-56; 'Assisting the Global Poor', in The Ethics of Assistance, ed. D. K. Chatterjee (UK: Cambridge University Press, 2007b), 260-89; Fiona Terry, Condemned to Repeat? The Paradox of Humanitarian Action (Ithaca, London: Cornell University Press, 2002).

${ }^{85}$ Séverine Autesserre, Peaceland Conflict: Resolution and the Everyday Politics of International Intervention (Cambridge: Cambridge University Press, 2014), 241-2.

${ }^{86}$ Barber, 'Feeding Refugees, or War?'; Barnett, The Empire of Humanity; Charles Boyd, 'Making Peace with the Guilty', Foreign Affairs (1995): 22-38; Cindy Collins and Thomas Weiss, Humanitarian Challenges and Intervention (Boulder, CO: Westview Press, 1996); Alex de Waal, Famine Crimes: Politics and the Disaster Relief Industry in Africa (Oxford: James Currey, 1997); Hoffman and Weiss, Sword \& salve; Lischer 'Dangerous Sanctuaries'; Pogge 'Moral Priorities for International Human Rights NGOs'; Terry, Condemned to Repeat?; Thomas Weiss, 'Principles, Politics, and Humanitarian Action', Ethics and International Affairs (1999): 1-22.

${ }^{87}$ Michael L. Gross, Bioethics and Armed Conflict: Moral Dilemmas of Medicine and War (Cambridge, MA: MIT Press, 2006). ${ }^{88}$ Ibid.
} 
There is no doubt that overall consequences matter and that the simple account of consequentialism stated above could be a way to resolve the humanitarian assistance dilemma. Indeed, at first glance, the simple account of consequentialism appears to be intuitively attractive, given that it rightly appeals to one's intuition that it is important to maximise harm-reduction. However, humanitarian agencies often have different beliefs about crisis response, holding different expectations of humanitarian assistance, subscribing to different principles of humanitarian action, and endorsing different ethical norms. It follows that different humanitarian agencies may face different moral dilemmas when delivering relief aid in conflicts. They may face volitional moral dilemmas, cognitive moral dilemmas, or social moral dilemmas, depending on their operational principles and organisational structures. ${ }^{89}$

For instance, volitional moral dilemmas pose predicaments to humanitarian agencies when they know what the right course of action is but are unsure whether they can perform the action successfully. Cognitive moral dilemmas, on the other hand, are dilemmas in which humanitarian agencies are unsure which action is best to take. Different to both volitional moral dilemmas and cognitive moral dilemmas, social moral dilemmas are dilemmas occurring in cases where different humanitarian agencies disagree on the right course of action..$^{90}$ It is therefore of great importance to lay out the five ethical quandaries facing humanitarian agencies when delivering relief aid in conflicts.

\section{Contemporary principles of humanitarian action analysed}

Due to the fact that humanitarian agencies often need to identify different ways the humanitarian assistance dilemma manifests itself in conflicts, and that different humanitarian agencies often endorse different values, two distinct schools of thought on principles of humanitarian action have been developed, and are adopted by contemporary aid agencies. They are traditional principles of humanitarian action and political principles of humanitarian action.

Traditional principles of humanitarian action consist of four humanitarian principles: the principle of humanitarian imperative (humanity), the principle of independence, the principle of impartiality, and the principle of neutrality. ${ }^{91}$ These traditional principles of humanitarian action are endorsed by agencies such as ICRC, the UN Office for the Coordination of Humanitarian Affairs (OCHA), and World Vision Australia. ${ }^{92}$ The principle of humanity affirms the view that humanitarian assistance is concerned with the condition of individuals solely with regard to their status as human beings, and hence should not be affected by other considerations. This demands that humanitarian assistance provides life-saving relief in the most imminent and life-threatening situations. The principle of independence, on the other hand, affirms the view that political engagement in armed conflicts can pose severe threats to aid workers and requires that humanitarian agencies refrain from connecting to any party with a stake in conflicts, or advancing political agendas of any party.

\footnotetext{
${ }^{89}$ James DuBois, Ethics in Mental Health Research: Principles, Guidance, Cases (New York: Oxford University Press, 2008).

${ }^{90}$ lbid.

${ }^{91}$ Barnett, The Empire of Humanity; Minear and Weiss, Humanitarian Action; Hoffman and Weiss, Sword \& Salve; Rieff, A bed for the Night.

${ }^{92}$ World Vision, World Vision Australia's Position on Humanitarian Principles, Humanitarian Principles World Vision Australia's Public Policy Position, July 2017.
} 
Although the notions of humanitarian imperative and independence remain the most important principles of humanitarian action in the traditional school of humanitarian operations, principles of impartiality and neutrality have attracted much criticism. As outlined earlier, while the principle of impartiality demands humanitarian agencies provide aid indiscriminately, the principle of neutrality demands humanitarian agencies stay neutral in the face of any unjust events. It follows that humanitarian agencies often enable belligerents and armed combatants to cause more harm by committing to traditional principles of impartiality and neutrality. Traditional principles of humanitarian action, in this sense, often face and pose challenge in conflict settings.

Seeing the obvious negative consequences of traditional principles of humanitarian action, contemporary theorists and aid practitioners such as Mark Duffield, Thomas Weiss, Laura Hammond and Hannah Vaughan-Lee propose political principles of humanitarian action that aim to incorporate political engagement with the operational context of conflicts. ${ }^{93}$ They argue that humanitarian assistance should not be about upholding principles of neutrality and impartiality but rather, should be about understanding 'how humanitarian action is political in its own right'. ${ }^{94}$ This view advocates the use of political operational principles that are partial and selective, as opposed to traditional operational principles of neutrality and impartiality. Political operational principles suggest humanitarian agencies allocate aid based on who is being helped and act in ways that take sides with those parties perceived to be just.

Although adopting political operational principles may potentially help humanitarian agencies minimise some of the negative impacts of aid, such principles over-emphasise the need for political engagement when humanitarian agencies discharge humanitarian assistance. Political operational principles, too, face and pose difficulties: political operational principles can lead to overall counter-productive effects when humanitarian agencies deliver aid. On the one hand, political operational principles' emphasis on political engagement can make armed combatants much more willing to harm aid workers in the field. This is because armed combatants often perceive and consider humanitarian agencies' humanitarian efforts as a tool used selectively by powerful external states for political purposes. Political operational principles of humanitarian action, in this sense, can create an adverse result and generate serious concern for aid workers' safety. ${ }^{95}$ On the other hand, political operational principles can severely hinder humanitarian agencies from performing their humanitarian missions successfully. This is because belligerents are very likely to deny humanitarian agencies access to the affected population if they are perceived as partial or allied with the opposite side. ${ }^{96}$ In light of this, humanitarian agencies should reconsider politicising humanitarian assistance, not only because political operational principles can impede aid delivery to the affected population, but also

\footnotetext{
${ }^{93}$ Mark Duffield, 'The Symphony of the Damned: Racial Discourse, Complex Political Emergencies and Humanitarian Aid', Disasters (1996); Weiss, 'Principles, Politics, and Humanitarian Action'; Laura Hammond and Hannah Vaughan-Lee, 'Humanitarian Space in Somalia: A Scarce Commodity', HPG Working Paper (2012).

${ }^{94}$ Hammond and Vaughan-Lee, 'Humanitarian Space in Somalia'.

${ }^{95}$ Francis Kofi Abiew, 'Humanitarian Action under Fire: Reflections on the Role of NGOs in Conflict and Post-Conflict Situations', International Peacekeeping (2012): 203-16; Hammond and Vaughan-Lee, 'Humanitarian Space in Somalia'; Søren Jessen-Petersen, Humanitarianism in Crisis (Washington, DC: U.S. Institute of Peace, 2011).

${ }^{96}$ Barnett, The Empire of Humanity; Michael Barnett and Thomas Weiss, Humanitarian in Question: Politics, Power, Ethics (Ithaca, NY: Cornell University Press, 2008); Hammond and Vaughan-Lee, 'Humanitarian Space in Somalia'.
} 
because taking sides can risk costing the lives of those in need and aid workers in the field. $^{97}$

It has been shown that traditional or political principles of humanitarian action do not offer clear guidance on the humanitarian assistance dilemma. Regardless of the validity of traditional or political principles of humanitarian action, they are not very helpful when it comes to the specific humanitarian assistance dilemma that confronts humanitarian agencies. In other words, traditional or political principles of humanitarian action do not clearly apply. An account of modified principles of humanitarian action to help humanitarian agencies address the humanitarian assistance dilemma is therefore necessary. Although I cannot develop a full account of all principles of humanitarian action here, this article aims to point out both sets/schools of principles' insufficiency in order to demonstrate a need for revision of contemporary humanitarian operational principles.

\section{Conclusion}

This article used the example of Tanzania to show how the humanitarian assistance dilemma arises, different ways the humanitarian assistance dilemma can manifest itself in conflicts, and its specific corresponding ethical predicaments. It first showed that the humanitarian assistance dilemma can manifest itself in conflicts when humanitarian assistance: relieves armed combatants' burden of sustaining costly conflicts; creates protected spaces for armed combatants; undermines local coping strategies; bestows legitimacy upon armed combatants; and directly feeds armed combatants. It then identified five distinct ethical predicaments that link humanitarian assistance to the humanitarian assistance dilemma in conflicts. These are: the ethical predicaments of providing incentives for conflicts; allowing human rights violations; creating refugees' dependency on aid; being complicit in armed combatants' wrongdoings; and feeding unjust combatants.

Finally, it shed light on five core moral quandaries aid agencies need to address in conflicts whether to: stay and continue to assist the most vulnerable populations but provide incentive for conflicts; set up refugee camps for the affected population but risk allowing human rights violations; provide presumptively important goods to refugees but risk creating their dependency on aid; collaborate with armed combatants but risk being complicit in their wrong-doing; and provide aid indiscriminately but risk enabling armed combatants to do more harm. These moral quandaries, altogether, pose an overall dilemmatic question to humanitarian agencies: should these agencies stay and continue to assist some refugees, or should humanitarian agencies leave and reallocate the aid to other places where aid has fewer negative impacts (and hence more people can benefit)?

To properly answer this question, there is a need for further investigation of different moral issues underlying the ethical constraints embedded in the humanitarian assistance dilemma and the entailed ethical predicaments. Although there are good reasons to think that relief aid exacerbates conflicts and generates more harm in the long run, and should

\footnotetext{
${ }^{97}$ Urvashi Aneja, 'International NGOs and the Implementation of the Norm for Need-Based Humanitarian Assistance in Sri Lanka', in Implementation and World Politics: How International Norms Change Practice, eds. A. Betts and O. Phil (UK: Oxford University Press, 2014), 85-101; Barnett, The Empire of Humanity; Stephen Hopgood, 'Saying No to Wal-Mart? Money and Morality in Professional Humanitarianism', in Humanitarian in Question: Politics, Power, Ethics, eds. M. Barnett and T. Weiss (London: Cornell University Press, 2008), 73-97.
} 
thus be withdrawn and reallocated, humanitarian agencies may want to stay stationed in areas of need for other weighty moral reasons, such as the moral significance of humanitarian assistance's non-instrumental values. Due to space limitation, this line of argument cannot be fully explored in this article.

The humanitarian assistance dilemma and its corresponding ethical predicaments associated with humanitarian assistance in Tanzania remain highly relevant to the existing literature on humanitarian assistance. Although the shifting nature of conflicts may pose new challenges to humanitarian agencies, the fundamental humanitarian assistance dilemma that confronts humanitarian agencies is essentially the same as in the past. This is because the decisions humanitarian agencies need to make regarding aid allocation (i.e. withdrawing, reallocating, or staying) when they encounter the humanitarian assistance dilemma in conflicts, as outlined in this article, remains the same.

\section{Acknowledgements}

I would like to express my deep gratitude to Professor Pattison and Dr Stephen de Wijze, my research supervisors, for their patient guidance, enthusiastic encouragement and useful critiques of this research work. I would also like to thank Dr Simon Chin-Yee, for his valuable and constructive suggestions. My grateful thanks are also extended to Ms Elizabeth Ditmanson for her help in proofreading. I would also like to extend my thanks to the Institute of European and American Studies, Academia Sinica, and National Applied Research Laboratories Policy Division for their help in offering me the resources and time required by the program.

\section{Disclosure statement}

No potential conflict of interest was reported by the author.

\section{Notes on contributor}

Wen-Chin Lung completed her Ph.D. in Politics at the University of Manchester in 2017. Her research analyses the extent to which humanitarian agencies have succeeded in carrying out humanitarian assistance in times of conflicts and wars, through examining humanitarian agencies' refugee policies with three distinctive theories, which concerns agential responsibilities, basic human rights, and duties of assistance: the duties one has to those whose vital interests she is able to fulfil and influence, where the duty arises in virtue of her specific role and responsibility.

\section{ORCID}

Wen-Chin Lung (D) http://orcid.org/0000-0002-2470-9802 